Research Paper

\title{
Targeting neurokinin-3 receptor: a novel anti-angiogenesis strategy for cancer treatment
}

\author{
Ting Wang ${ }^{1, *}$, Siwei Chen ${ }^{1, *}$, Shihui Wang ${ }^{1}$, Liang Shi ${ }^{1}$, Chenggong Wang ${ }^{1}$, Jingxin \\ Zhang ${ }^{1}$, Yanfeng Gao ${ }^{1}$, Guodong $\mathrm{Li}^{1}$, Yuanming $\mathbf{Q i}^{1}$, Xiuli An ${ }^{1}$ and Lixiang Chen ${ }^{1}$ \\ ${ }^{1}$ School of Life Science, Zhengzhou University, Zhengzhou, 450001, P.R. China \\ *These authors contributed equally to this work \\ Correspondence to: Lixiang Chen, email: Ixchen@zzu.edu.cn \\ Yuanming Qi, email: qym@zzu.edu.cn \\ Xiuli An, email: anxI@zzu.edu.cn
}

Keywords: anti-angiogenesis, neurokinin 3 receptor, neurokinin B, antitumor therapy

Received: August 16, 2016 Accepted: April 06, $2017 \quad$ Published: April 19, 2017

Copyright: Wang et al. This is an open-access article distributed under the terms of the Creative Commons Attribution License 3.0 (CC BY 3.0), which permits unrestricted use, distribution, and reproduction in any medium, provided the original author and source are credited.

\section{ABSTRACT}

Angiogenesis is essential for tumor growth and metastasis, controlling angiogenesis is a promising strategy in cancer treatment. However, thus farther severe side effects of anti-angiogenic drugs have been rather demonstrated, stimulating interest in seeking novel targets of anti-angiogenesis. Neurokinin receptors, also known as tachykinin receptors, are usually considered as drug targets due to diverse physiological functions and their tractability. Although Neurokinin B, the selective natural agonist of neurokinin-3 receptor, have been shown to exhibit anti-angiogenesis activity, the effect and mechanism of neurokinin-3 receptormediated angiogenesis still remains unclear. In the present study, we demonstrated that [Mephe7]NKB, an analogue of NKB, possess significant anti-angiogenic effect on CAM. Furthermore, by introducing the tumor angiogenesis homing sequence (NGR), we designed and synthesized two novel agonist analogues of NK3R, NK3R-A1 and NK3R-A2. Both of the two analogues exhibit more efficient anti-migration effect on HUVECs by activating NK3R in vitro, and showed potent antitumor activities with no significant side effects in vivo. Taken together, our results illuminated that NK3R might be a potential novel target for the anti-angiogenesis therapy. Notably, NK3R-A1 might be used as a template for the development of the anti-tumor drugs on the basis of the anti-angiogenesis strategy.

\section{INTRODUCTION}

Since the importance of angiogenesis in tumor development has been recognized over decades [1], interest in the therapeutic potential of anti-angiogenic treatments has continued to grow [2]. The most validated anti-angiogenic strategies act on the VEGF axis, blocking VEGF directly with the neutralizing antibody bevacizumab or the aflibercept (VEGF trap), or indirectly with low-molecular-weight tyrosine kinase VEGF receptor inhibitors (e.g., sunitinib, sorafenib, and pazopanib) [3]. Nonetheless, clinical applications have not got the expected results, only a fraction of cancer patients show benefit as tumors evolve mechanisms of resistance or are refractory toward VEGF (receptor) inhibitors or occur severe side effect, such as bleeding and chemoresistance [4-7]. The limitation of current antiangiogenic strategies stimulate our interests in finding novel targets for anti-angiogenesis therapy.

Tachykinin receptors, known as neurokinin (NK) receptors, are usually considered therapeutically important due to diverse physiological functions and their tractability as drug targets $[8,9]$. Neurokinin B (NKB), the most potent natural agonist ligand for NK3 receptor (NK3R), has been reported to play a vital role in many potentially life threatening disease. Pal et al. demonstrated that NKB could target endothelium via a multi-component mechanism to oppose vascular remodeling and act as an endogenous angiogenesis inhibitor [10]. Thus, we proposed a hypothesis that NK3R might function as a potential 
novel target for the anti-angiogenesis therapy through the interactions with agonist and analogues of NK3R.

Agonist binding to the receptor is a critical key in initiating signaling and triggering effects, therefore the declaration of structural features of the agonists not only can reveal the molecular basis of receptor activation but also will help in rational design of novel therapeutics. The pharmacology of the NK3R is less well characterized in comparison of NK1 and NK2 receptors. Several agonists derived for the NK3R have been obtained by modification of the primary structure of NKB [11]. [MePhe $\left.{ }^{7}\right] \mathrm{NKB}$, a classical synthetic agonist, has been used extensively to study the role of NK3R and [Gly $\left.{ }^{6}\right] \mathrm{NKB}[3-10]$ has been used to facilitate the study of putative NK3R antagonists $[12,13]$. Studies with chimeric NK1/NK3 receptors have identified that the carboxyl terminal domain, part of the third extracellular loop and the seventh transmembrane region of the NK3R, is important for NKB binding [14]. Therefore, in order to maintain maximal binding stability and reinforce the affinity with the NK3R, we kept the $\mathrm{NKB}$ [4-10] motif and replaced $\mathrm{Val}^{7}$ with $\mathrm{MePhe}^{7}$.

On the other hand, we considered to bring in additional motif to reinforce tumor targeting effect of analogues of NK3R agonist. A critical component of molecular targeting is the identification of a marker, for instance angiogenic or "activated" endothelium. Novel markers of angiogenic endothelium and their ligands have been identified by various phage display experiments in tumor models. NGR (Asn-Gly-Arg) have been shown to home specifically to tumor vessels in tumor xenograft bearing mice [15]. In addition, NGR conjugated peptides showed a greater anti-tumor effect than uncoupled drugs $[16,17]$. The vascular address for NGR has been identified as CD13/APN (aminopeptidase N, also named CD13), which was found to be target for anti-cancerous therapy because of its functional association with the growth of different human cancers. APN could function as the dominating receptor for the NGR peptide motif and this receptor is expressed exclusively on the endothelial cells of tumor vessels in the subsequent research [18-20]. In particular, NGR and Cysteine-asparagine-glycinearginine-cysteine (CNGRC), which was derived from NGR peptide, have been proven to be useful for delivering cytotoxic drugs, proapoptotic peptides, and tumor necrosis factor- $\alpha$ (TNF) to tumor vasculature.

Here, our result showed that the agonist of NK3R, $\left[\mathrm{MePhe}^{7}\right] \mathrm{NKB}$, could elicit significant anti-angiogenic effect in vitro and in vivo. Two novel analogues, NK3R-A1 and NK3R-A2, were designed by coupling the targeting anti-tumor motif NGR/CNGRC and the NK3R high affinity binding sequence with a glycinyglycine (GG) bridge to impart peptide flexibility and minimize potential steric interactions that would prevent binding. Further functional assay indicated that the NK3R analogues exhibit more efficient anti-migration effect than [MePhe ${ }^{7}$ NKB on HUVECs by activating NK3R in vitro, and showed no significant side effects on potent antitumor activities in vivo. Taken together, our results illuminated that NK3R might be a potential novel target for the antiangiogenesis therapy. Notably, the modified molecular modeling of the most effective analogue, NK3R-A1, might provide novel insight into the development of antitumor drugs on the basis of the anti-angiogenesis strategy.

\section{RESULTS}

\section{The anti-angiogenic effect mediated by activating NK3R on CAM}

CAM assays were conducted to access whether $\mathrm{NKB}$ possess the anti-angiogenic property through its putative receptor, NK3R. Compared to the controls, $1 \mu \mathrm{M}$ of NKB significantly reduced vascular density and bed area to $38.6 \%$ and $20.9 \%$, respectively (Figure 1A-1C). [Gly ${ }^{6}$ NKB [3-10], selective antagonist of NK3R, was used for antagonism assay. We found $\left[\mathrm{Gly}^{6}\right] \mathrm{NKB}$ [3-10] could dramatically antagonize the effects of NKB to reduce the density of capillary and bed area of the chorioallantois microvessels, while showed no effects alone (Figure 1A, 1D-1E). Our results suggested that NKB possess the anti-angiogenic effect through activating NK3R.

\section{Selective agonist analogues of NK3R exert anti- angiogenic property on CAM through NK3R}

To examine if NK3R could be an effective target for anti-angiogenic strategy, one efficient agonist of NK3R, $\left[\mathrm{MePhe}^{7}\right] \mathrm{NKB}$ and two novel designed analogues of NK3R agonist, NK3R-A1 and NK3R-A2 were estimated in CAM assay (Figure 2A). [MePhe ${ }^{7} \mathrm{NKB}$ inhibited the expansion of the microvasculature by $\sim 30 \%$ at a dose of $50 \mathrm{nM}$ (Figure 2B-2C). Meanwhile, $100 \mathrm{nM}$ of NK3R-A1 and NK3R-A2 remarkably reduced vascular density to $48.4 \%$ and $31.6 \%$, and vascular bed area descended to $53.8 \%$ and $30.7 \%$, compare to PBS control, respectively (Figure 2D-2E). As we demonstrated earlier, the antiangiogenic effect of NKB was triggered through NK3R. By pre-treatment with $\left[\mathrm{Gly}^{6}\right] \mathrm{NKB}[3-10]$, the anti-angiogenic effects of $\left[\mathrm{MePhe}^{7}\right] \mathrm{NKB}$ and two novel designed analogues, were all blocked on CAM in vascular densities and bed areas (Figure $2 \mathrm{~F}-2 \mathrm{G}$ ). These results indicated that NK3R interaction with all three peptides appear to mediate the blockade of angiogenesis in the CAM assay.

To confirm that our designed peptides indeed possess the property of anti-angiogenesis, especially for neovascularization at microscopic level on histological sections, we further performed gelatin sponge-CAM assay (shown in Figure 2H). Treating with $50 \mathrm{nM}\left[\mathrm{MePhe}^{7}\right] \mathrm{NKB}$, $100 \mathrm{nM}$ NK3R-A1 or100 nM NK3R-A2 respectively, the number of new vessels were decreased dramatically. The antagonist of NK3R, [Gly $\left.{ }^{6}\right] \mathrm{NKB}[3-10]$, which did not exhibit obvious anti-angiogenic effect alone, was found 
to antagonize the anti-angiogenic effects of $\left[\mathrm{MePhe}^{7}\right]$ NKB, NK3R-A1 and NK3R-A2. All the data confirmed that $\left[\mathrm{MePhe}^{7}\right] \mathrm{NKB}$ and our novel designed peptides, NK3R-A1 and NK3R-A2, can induce the suppression of neovascularization in the NK3R-dependent manner.

\section{NK3R-A1, NK3R-A2 and [MePhe ${ }^{7}$ NKB could suppress the migration of HUVECs in vitro}

We next detected the anti-angiogenic effect of peptides in vitro. Given the importance of proliferation and mobility of HUVECs for neovascularization, MTT, wound healing and Transwell migration assays were conducted to further explore the effects of the peptides on HUVECs. In MTT assay, there is no markedly inhibition effects on the proliferation of
HUVECs that were treated with [MePhe $\left.{ }^{7}\right] \mathrm{NKB}, \mathrm{NK} 3 \mathrm{R}-\mathrm{A} 1$ and NK3R-A2 for 24 hours (Data not shown).

In contrast, the peptides exhibit significant affect on the migration ability of HUVECs. Figure $3 \mathrm{~A}-3 \mathrm{~B}$ shows the results of the migration of HUVECs toward a pseudo-wound inflicted on a monolayer of cells at 0 - and 24-hours, respectively. The results revealed that NK3R agonist analogues significantly decrease the closure rate of the wounded area. At around 24 hs post wounding, $>50 \%$ of the wounded areas still remain unclosed of the $N K 3 R-A 1$ or $N K 3 R-A 2$ treated group (Figure $3 \mathrm{~A}-3 \mathrm{~B}$ ), while the wound area of control group nearly complete closed.

In parallel, anti-migration effects of peptides were further demonstrated in Transwell migration assay. At 12 hours after seeding, the numbers of migrated HUVECs
A

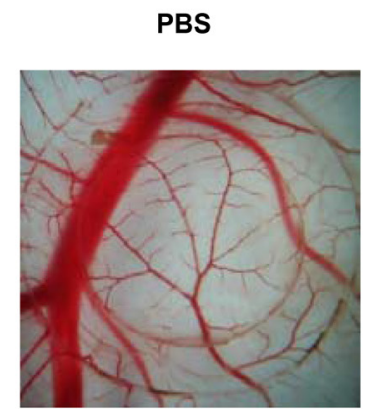

NKB $1 \mu \mathrm{M}$

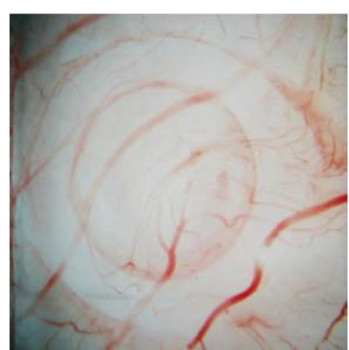

[Gly $]$ NKB[3-10]

$1 \mu \mathrm{M}$

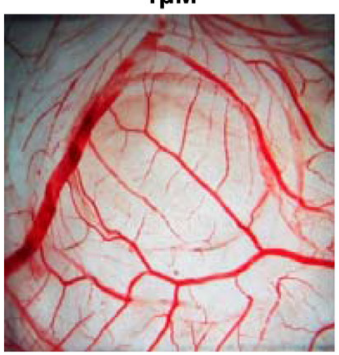

$\left[\mathrm{Gly}^{6}\right] \mathrm{NKB}[3-10] 1 \mu \mathrm{M}$ + NKB $1 \mu \mathrm{M}$

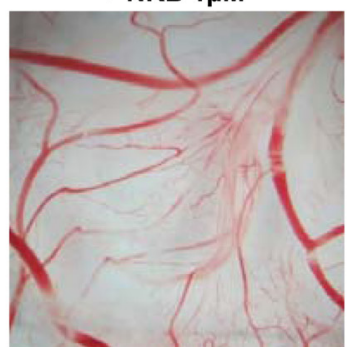

B

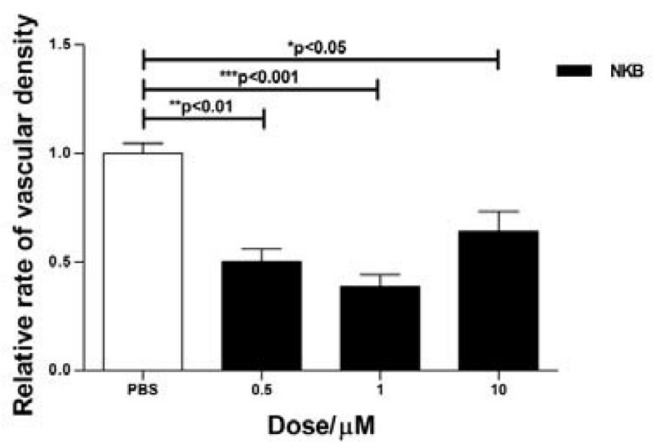

D

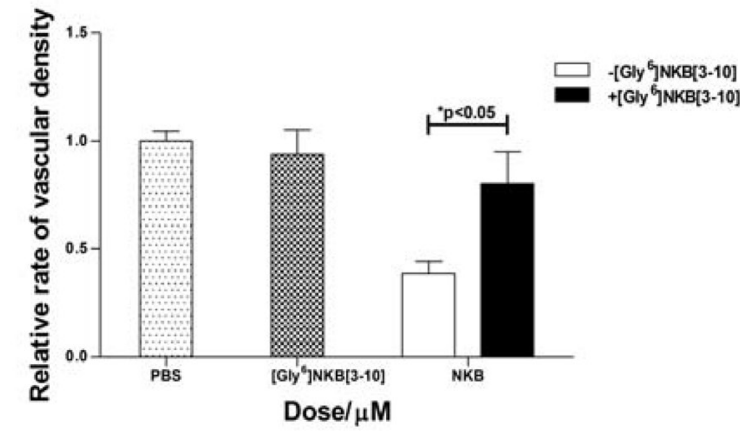

C

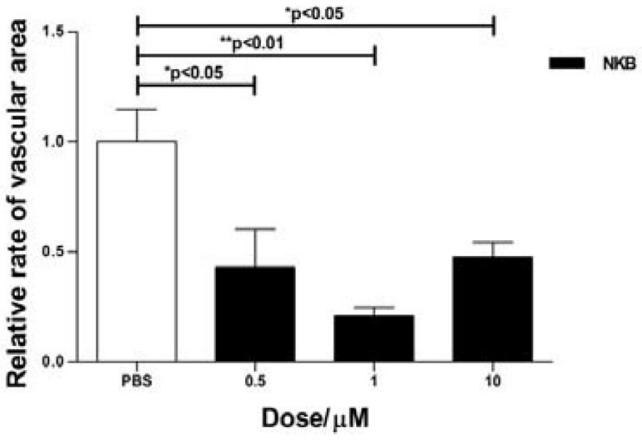

E

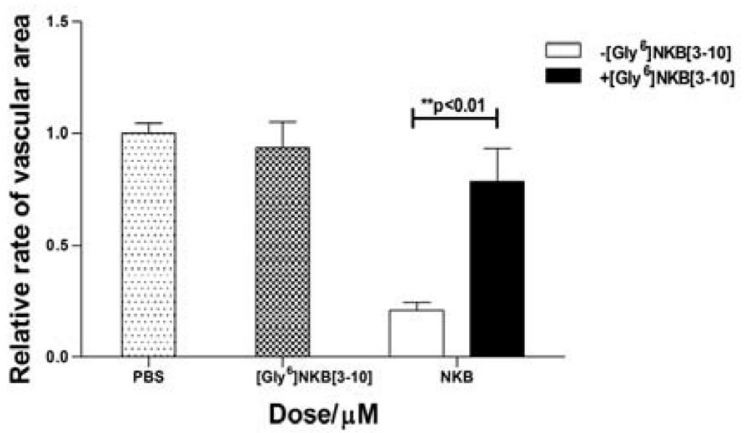

Figure 1: The anti-angiogenic effect of NKB mediated by NK3R on CAM. (A) Egg CAM was assayed in chick embryos as described in Materials and Methods. PBS, [Gly $\left.{ }^{6}\right] \mathrm{NKB}[3-10]$, NKB or a combination of [Gly $\left.{ }^{6}\right] \mathrm{NKB}[3-10]$ was applied to the CAM of day 8 chicken embryos. After 48 h, CAMs were dissected out and the representative areas were photographed $(n=10)$. The column charts displayed the relative rate of vascular density $(\mathbf{B}, \mathbf{D})$ and area $(\mathbf{C}, \mathbf{E})$ treated with NKB or co-treated with NKB and $\left[\mathrm{Gly}{ }^{6}\right] \mathrm{NKB}[3-10]$. Data are mean \pm SEM from three independent experiments. ${ }^{*} p<0.05 ; * * p<0.01 ; * * *<0.001$. 
of NK3R-A1 or NK3R-A2 (5 $\mu \mathrm{M})$ treated group were 4- and 9-fold less than the control group, respectively (Figure 3C-3E). All the results elucidated that NK3R-A1, NK3R-A2 and [MePhe ${ }^{7}$ NKB possessed the property of antimigration in vitro, and two NK3R agonists analogues showed profound inhibitory effect than that of $\left[\mathrm{MePhe}^{7}\right] \mathrm{NKB}$.

\section{NK3R antagonist $\left[\mathrm{Gly}^{6}\right] \mathrm{NKB}[3-10]$ could antagonize the anti-angiogenic effect induced by the analogues in vitro}

$\left[\mathrm{Gly}^{6}\right] \mathrm{NKB}[3-10]$, specific antagonist of NK3R, was used to further declare the mechanism of the antiangiogenesis effects of the tested peptides. The closure of the wound areas of cells that treated with $\left[\mathrm{Gly}^{6}\right]$ NKB[3-10] 1 hour before adding NK3R-A1 or NK3R-A2 were nearly complete, reached to $\sim 90 \%$ after 24 hours (Figure 4A-4C). Moreover, the anti-migration activity of $\left[\mathrm{MePhe}^{7}\right] \mathrm{NKB}$ was also significantly suppressed by $\left[\mathrm{Gly}^{6}\right]$ NKB[3-10] (Figure 4A and 4D).

The antagonist of NK3R countervailed the inhibition effect of all agonist analogues of NK3R, which was able to be further verified in Transwell migration assay. Pretreated with $\left[\mathrm{Gly}^{6}\right] \mathrm{NKB}[3-10]$ 1h before adding either NK3R-A1, NK3R-A2 or $\left[\mathrm{MePhe}^{7}\right] \mathrm{NKB}$, the number of migrated cells dramatically increased than that of the $\left[\mathrm{Gly}^{6}\right] \mathrm{NKB}[3-10]$ non-treated group (Figure 4E-4H). These findings strongly suggest that NK3R is crucial for the anti-angiogenic activity of the peptides, which means NK3R might be the main target of these testing peptides to drive the function of anti-angiogenesis.

\section{Antitumor activity of the agonist analogues in S180 sarcoma-bearing BALB/c mice}

To characterize the in vivo anti-angiogenic activities of the agonist analogues against tumor, S180 sarcoma cells were harvested in $\mathrm{BALB} / \mathrm{c}$ mice and antitumor properties were analyzed. Experimental results indicated that tumor volume gap between peptides treated and NS control animals progressively increased. And at the end of the experiment, tumor volume of peptides treated groups were over 2 times smaller than those of the control, which illustrated that three agonist analogues of NK3R did counteract the tumor growth in S180 tumorbearing mice without markedly changes of body weight (Figure 5A-5C). As shown in Figure 5D-5E, the tumor weights of the peptides-treated groups were significantly decreased as compared to the negative control. The IHC staining results (Figure 5F-5G) showed that the microvessel density (MVD) of stained tissues were overtly decreased than that of negative control, which illustrated that the peptides possess anti-angiogenesis activity in vivo. In sum, all the results indicated that both NK3R-A1 and

\section{A}
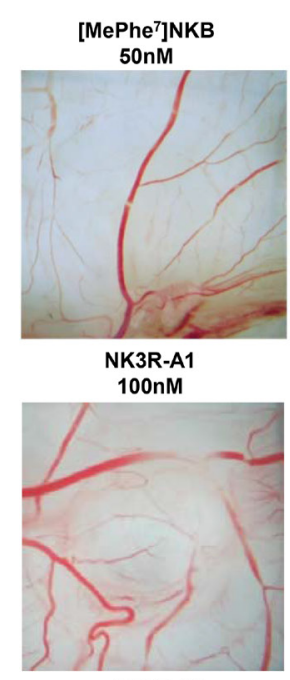

NK3R-A2 $100 \mathrm{nM}$

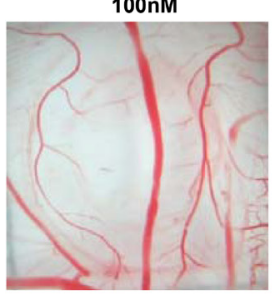

[Gly6]NKB[3-10] $1 \mu \mathrm{M}$ $+\left[\mathrm{MePhe}^{7}\right] \mathrm{NKB}$ 50nM

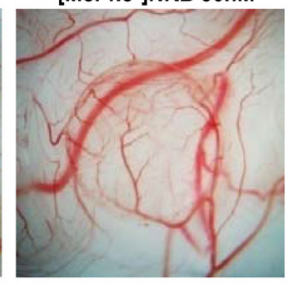

[Gly6]NKB[3-10] $1 \mu \mathrm{M}$ + NK3R-A1 100nM

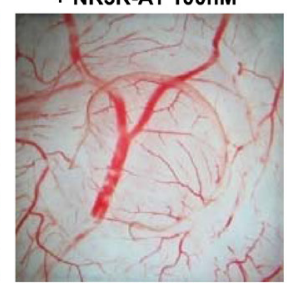

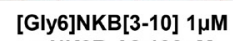
+ NK3R-A2 100nM

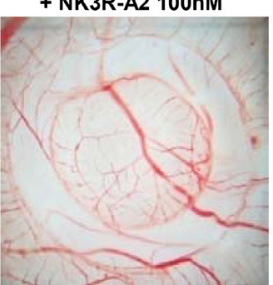

B

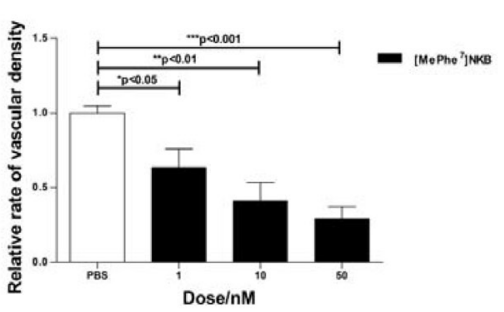

D

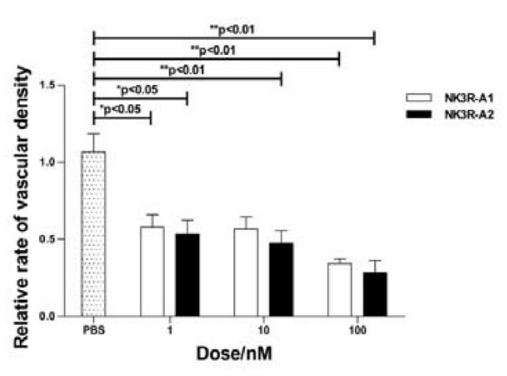

$\mathbf{F}$

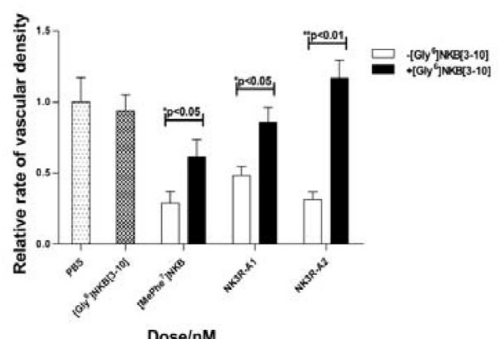

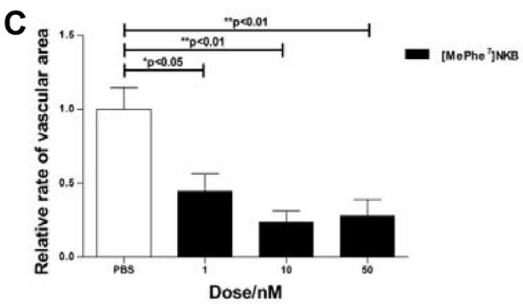

E

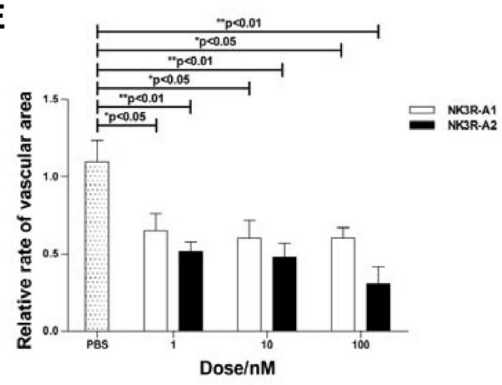

G

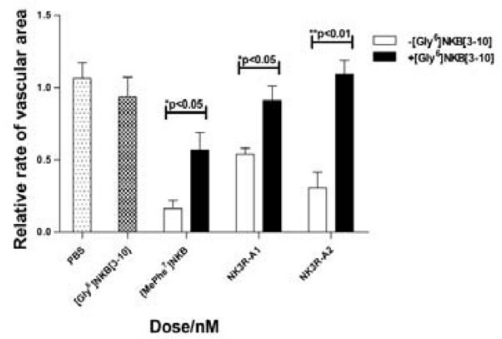


H

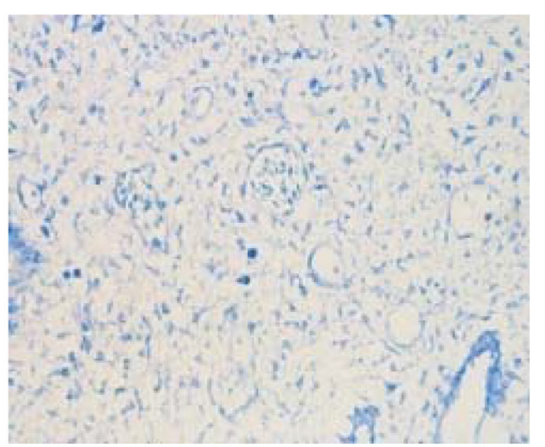

FGF2 30pM

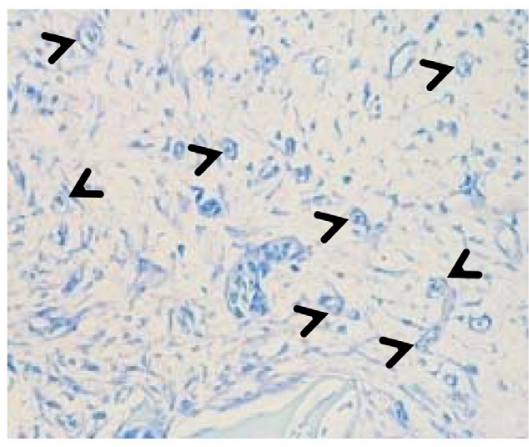

[Gly6]NKB[3-10] $1 \mu \mathrm{M}$

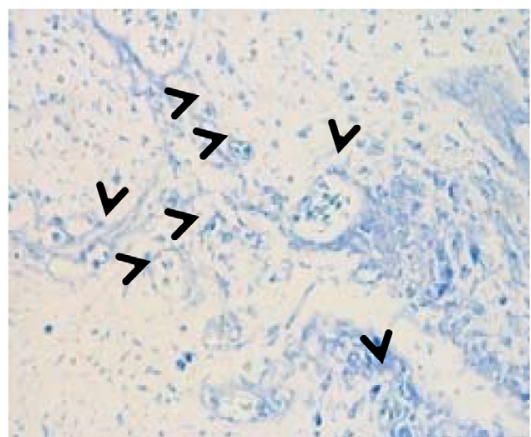

[MePhe ${ }^{7}$ NKB 50nM

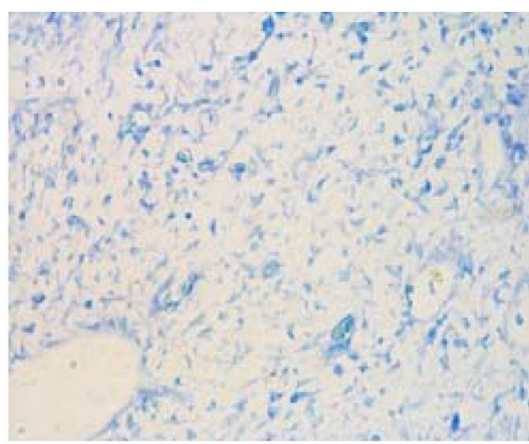

NK3R-A1 100nM

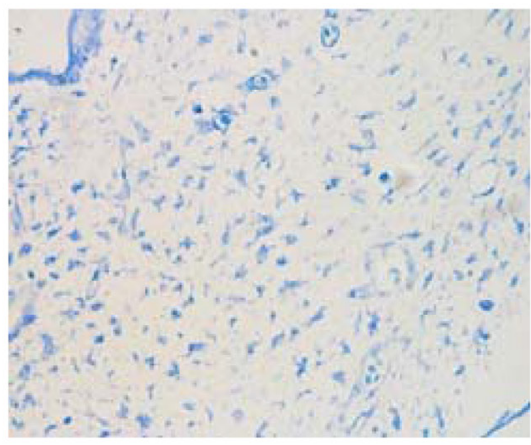

NK3R-A2 100nM

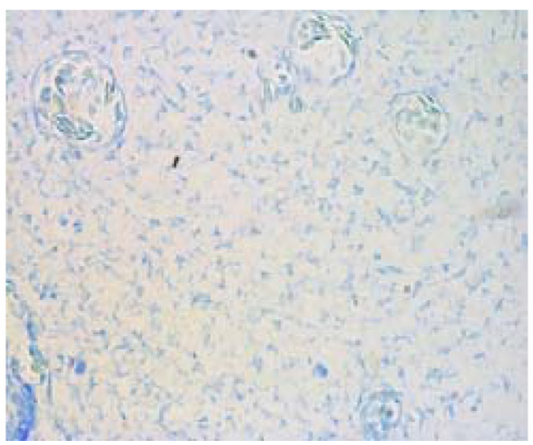

[Gly $\left.{ }^{6}\right]$ NKB[3-10] $1 \mu \mathrm{M}$

$+\left[\mathrm{MePhe}^{7}\right] \mathrm{NKB}$ 50nM

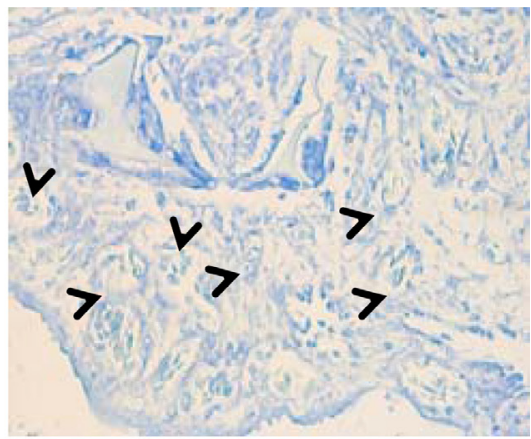

[Gly $]$ NKB[3-10] $1 \mu \mathrm{M}$ +NK3R-A1 100nM

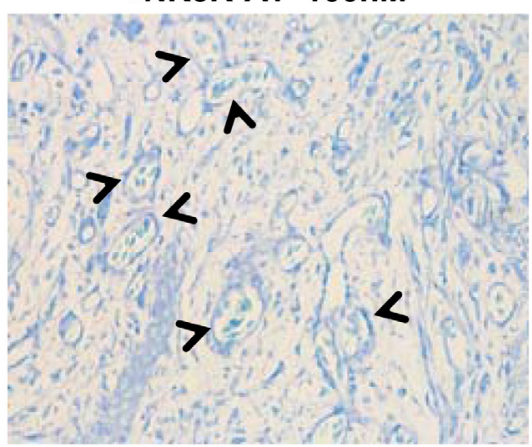

[Gly ${ }^{6}$ ]NKB[3-10] $1 \mu \mathrm{M}$ +NK3R-A2 100nM

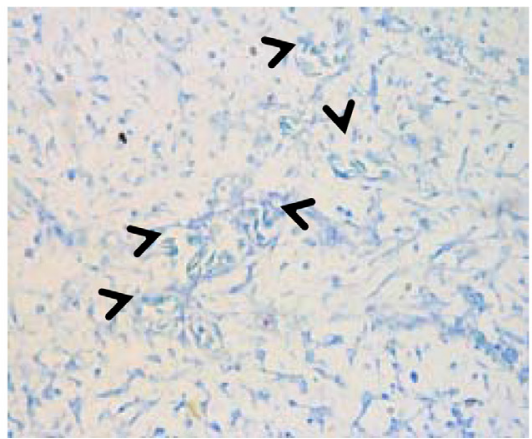

Figure 2: NK3R selective agonist analogues exert anti-angiogenic property on CAM through NK3R. (A) Chick CAM assay of angiogenesis. [MePhe ${ }^{7}$ NKB, NK3R-A1, NK3R-A2, or a combination of [Gly ${ }^{6}$ NKB[3-10], respectively, was applied to the CAM of day 8 chicken embryos. The representative photos are taken after $48 \mathrm{~h}(n=10)$. The columncharts displayed the relative rate of vascular density $(\mathbf{B}, \mathbf{D})$ and area $(\mathbf{C}, \mathbf{E})$ of $\left[\mathrm{MePhe}^{7}\right] \mathrm{NKB}$, NK3R-A1 and NK3R-A2 treated group, respectively, or the relative rate of vascular density $(\mathbf{F})$ and area $(\mathbf{G})$ co-treated with NK3R selective agonist analogues and [Gly $]$ NKB[3-10], respectively. (H) The gelatin spongeCAM assay of neovascularization at microscopic level on histological sections. Representative photos are shown $(400 \times)$. Data are mean \pm SEM from three independent experiments. $* p<0.05 ; * * p<0.01 ; * * * p<0.001$.

NK3R-A2 had potent in vivo antitumor effects on S180 sarcoma bearing mice.

\section{DISCUSSION}

In our present work, we proposed a tactics to design analogues of NK3R agonist which has the antiangiogenesis activity targeting to the blood vessels of tumors. The results demonstrated that the anti-angiogenic activity of three novel peptides, [MePhe $\left.{ }^{7}\right] \mathrm{NKB}, \mathrm{NK} 3 \mathrm{R}-\mathrm{A} 1$ and NK3R-A2, were induced by activating NK3R. Our findings suggested that NK3R might be a novel potential target for the anti-angiogenesis strategy. The anti-angiogenic peptide NK3R-A1 could be used as an template for the development of novel anti-tumor drugs.

Tumor angiogenesis is a complicated process that perturbed the balance between pro-angiogenic and anti-angiogenic mechanisms [21]. During the last three decades, numerous cytokines have been proven to be crucial for tumor related angiogenesis through mediating 
vasculogenesis, angiogenic remodeling, angiogenic sprouting, and vascular permeability, VEGF is wellknown among them $[22,23]$. However, with the deepening of the investigations, some limitations of VEGFrelated antibodies have been exposed. Bevacizumab in combination with bolus-IFL chemotherapy could increase the risk of suffering gastrointestinal perforation [24]. Ebos JM et al. showed that sunitinib, the VEGFR/PDGFR kinase inhibitor, could accelerate metastatic tumor growth and decrease overall survival in mice after receiving short-

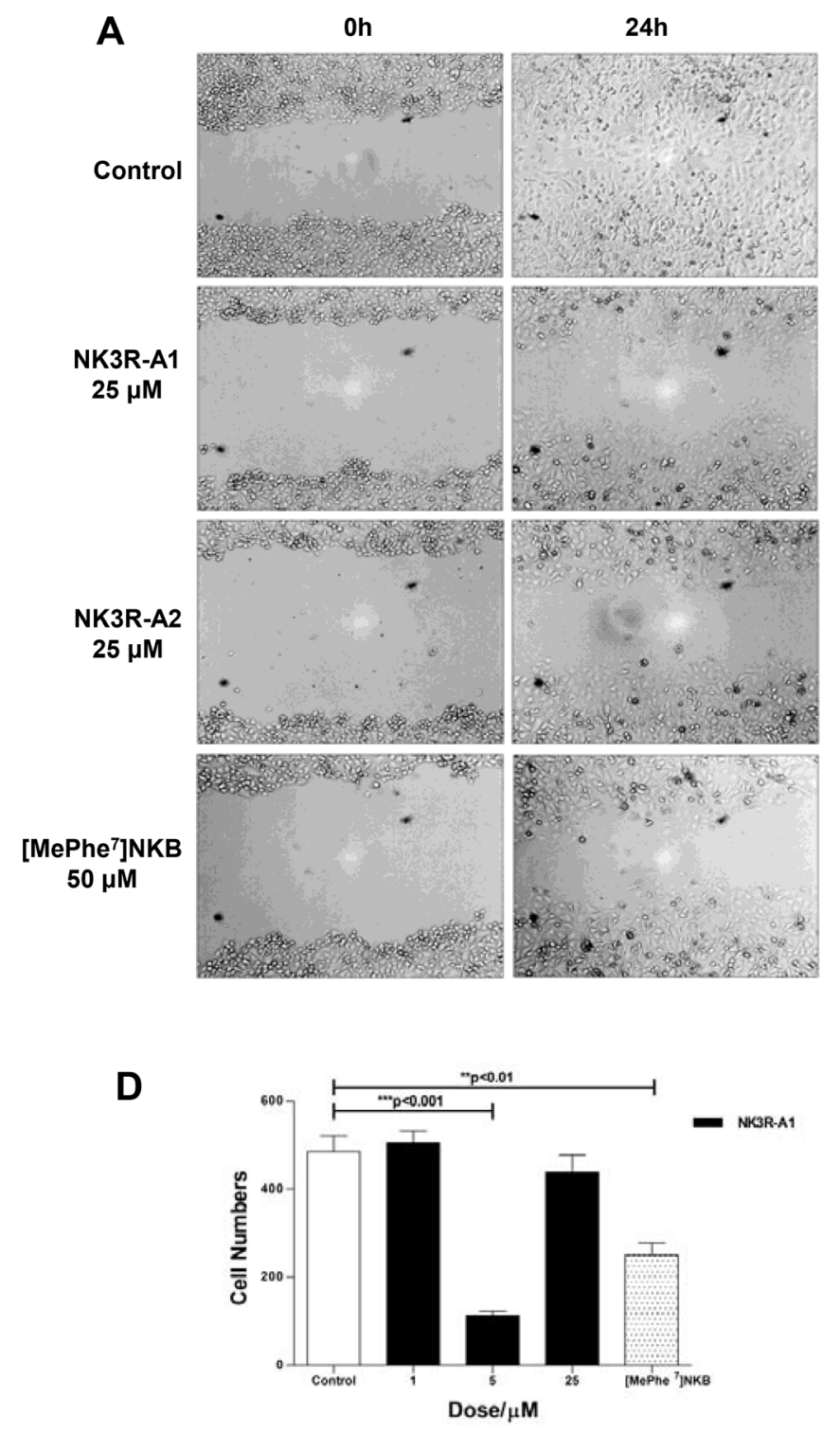

term therapy in various metastasis assays [25]. Thus, it is essential to find some novel targets to extend the antiangiogenic strategy.

NK3R, member of tachykinins receptors, is a class A GPCR preferentially activated by NKB peptide, which together with senktide (a synthetic peptide) are the only known potent and selective agonists of NK3R [26]. Numerous studies indicated that the function of NK3R related to tachykinins exert a plethora of biological effects, including smooth muscle contraction and relaxation,

B

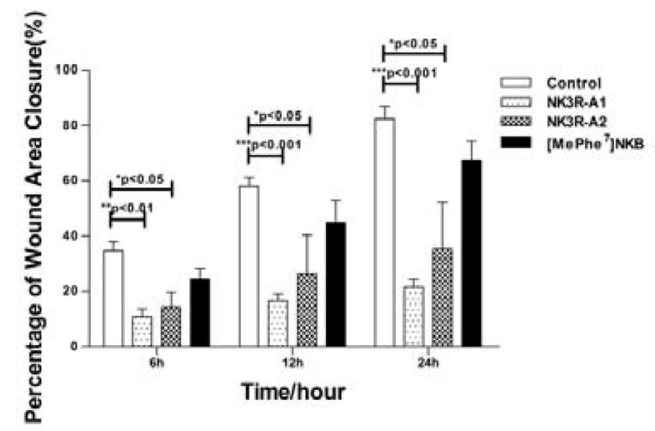

C

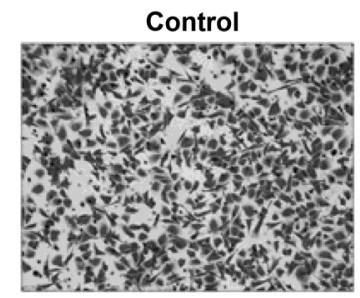

NK3R-A1 5 $\mu M$

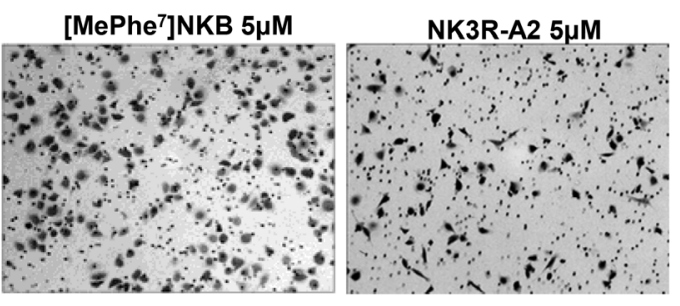

$\mathbf{E}$

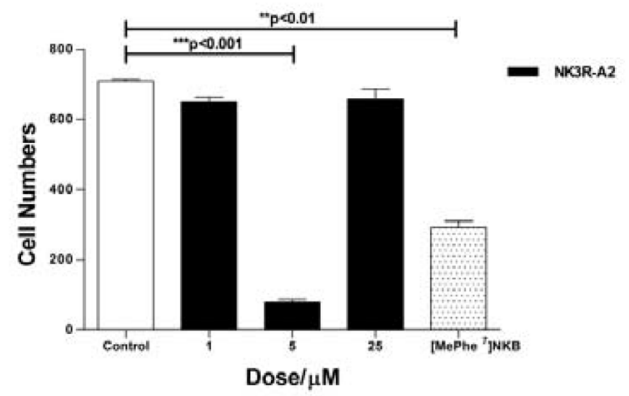

Figure 3: NK3R-A1, NK3R-A2 and [MePhe] $\mathrm{NKB}$ could suppress the migration of HUVECs in vitro. (A-B) Wound healing assay. HUVECs were treated with PBS, NK3R-A1, NK3R-A2 or [MePhe $\left.{ }^{7}\right]$ NKB. During 24 h healing period, the cells migrating into the wound area were visualized and the digital images were captured for every $6 \mathrm{~h}$, and representative photos were shown $(200 \times)$ (A). (B) The histograms showed the relative width of the wound area within $24 \mathrm{~h}$ treated with the optimal concentration of NK3R-A1, NK3R-A2 and [MePhe ${ }^{7}$ NKB, respectively. (C-E) Transwell migration assay. HUVECs treated with NK3R-A1, NK3R-A2 and [MePhe $\left.{ }^{7}\right]$ NKB were seeded as indicated in the upper chamber. After $12 \mathrm{~h}$ incubation, the migrated cells were stained with hematoxylin and photographed $(C)$ and representative images were shown $(200 \times)$. The histograms reflected the number of migrated HUVECs treated with a range of concentration of NK3R-A1 (D) or NK3R-A2 (E) in $12 \mathrm{~h}$. Data are mean \pm SEM from three independent experiments. $* p<0.05$; $* * p<0.01 ; * * * p<0.001$ 
vasodilatation, secretion, activation of the immune system, pain transmission and neurogenic inflammation, and are implicated in a broad range of CNS disorders $[27,28]$. Here, we described further evidence that NKB could function as an endogenous angiogenesis inhibitor. Our results also provided novel evidence that the antiangiogenesis of NKB and its analogues were elicited by activating NK3R, suggesting that NK3R might be a novel potential target for anti-angiogenesis therapeutics.

$\left[\mathrm{MePhe}^{7}\right] \mathrm{NKB}$, another efficient active agonist of NK3R by replacing $\mathrm{Val}^{7}$ of $\mathrm{NKB}$ with MePhe, has been utilized in our investigation. We demonstrated that $\left[\mathrm{MePhe}^{7}\right] \mathrm{NKB}$ which exert even more efficient antiangiogenic effect compared with NKB on CAM assay and gelatin sponge-CAM assay. And the corresponding competitive assay we performed using the antagonist of NK3R, [Gly $\left.{ }^{6}\right] \mathrm{NKB}[3-10]$, showed that it almost completely antagonize the effects of both peptides. In consideration that $\mathrm{NKB}[4-10]$, which has been found to be the minimum active sequence of NKB [29], also elicited significant anti-angiogenesis effect in CAM assay (data not shown), [MePhe $\left.{ }^{7}\right] \mathrm{NKB}[4-10]$ was therefore singled out for the designation of these two agonist analogues of NK3R, NK3R-A1 and NK3R-A2.

In addition, due to the NK3R is widely distribution, it is necessary to restrict the target selectivity of NK3R and its analogues to the tumor angiogenesis area. Arg-Gly-Asp (RGD) and Asn-Gly-Arg (NGR)are two peptide motifs have been well characterized with known recognition sites among various peptides identified through phage-display to target the tumor vessels of a mouse model. NGR was found to bind the aminopeptidase N (APN/CD13) receptor isoform that is upregulated in tumor vasculature, and shows a three-fold higher specificity than the RGD peptide toward tumor area $[19,20]$. In addition, as an endothelial cellsurface receptor of NGR sequence, APN is concentrated on the apical surface of forming blood vessels and is absent or barely detectable in established blood vessels [30]. Colombo and co-workers have confirmed the affinity to its receptor and antitumor activity of linear peptide CNGRC could be lower than that of cyclic peptide c(CNGRC), demonstrating that the disulfide bridge constraint was vital for stabilizing the bent conformation and for increasing the tumor targeting efficiency [31]. With these advantages, the NGR peptide-based drug delivery and imaging studies have been an emerging strategy in anticancer research [32, 33].

To extend the function of NK3R agonists serving as a valid inhibitor of angiogenesis with the selectivity targeting property to the tumor related angiogenesis site, two endothelial cells targeting sequence, NGR and CNGRC, were used to construct novel anti-angiogenic peptide analogues. A GG bridge were utilized to couple
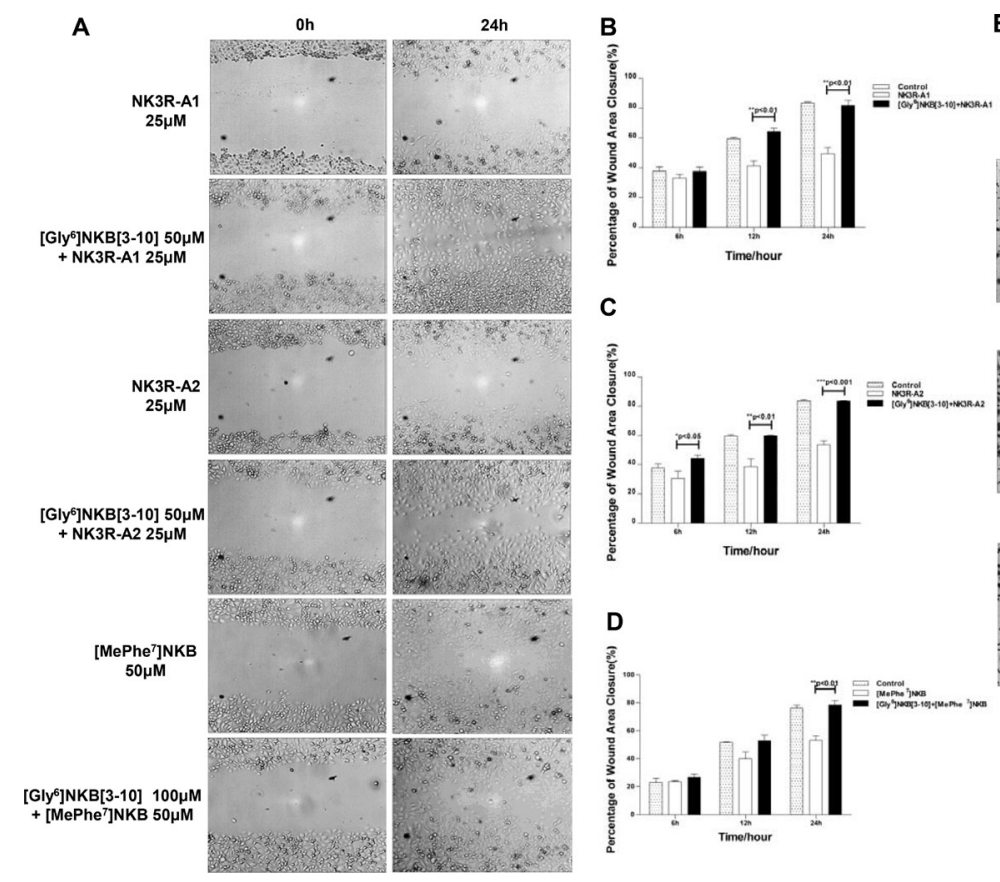

E
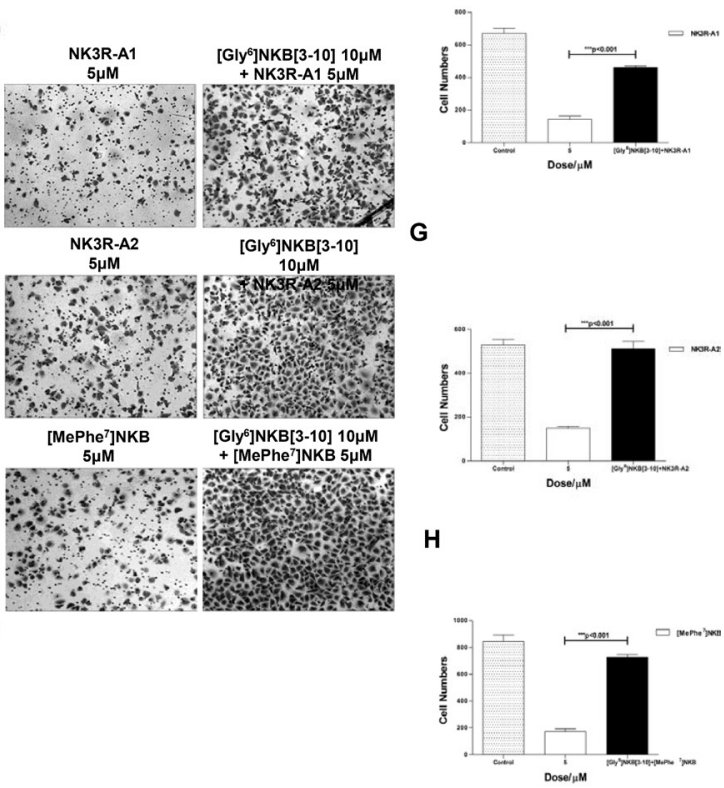

Figure 4: NK3R antagonist [Gly6]NKB[3-10] could antagonize the anti-angiogenic effect induced by NK3R-A1, NK3R-A2 and [MePhe7]NKB in vitro. (A-D) Competitive antagonism was measured by using [Gly ${ }^{6}$ NKB[3-10] in Wound healing assay. (A) HUVECs were treated with PBS, NK3R-A1, NK3R-A2 or [MePhe $\left.{ }^{7}\right]$ NKB alone, or co-treated with [Gly $]$ NKB[3-10]. During $24 \mathrm{~h}$ healing period, the cells migrating into the wound area were photographed for every 6 hand representative photos were shown $(200 \times)$. The analysis of the relative width of wound area was displayed in column chart (B-D). (E-H) Competitive antagonism was measured by using $\left[\mathrm{Gly}^{6}\right] \mathrm{NKB}[3-10]$ in Transwell migration assay.The representative images are shown $(200 \times)$. (E) The histograms indicated the numbers of migrated HUVECs co-treated with [Gly $\left.{ }^{6}\right] \mathrm{NKB}[3-10]$ and NK3R-A1 (F), NK3R-A2 (G) or [MePhe $\left.{ }^{7}\right] \mathrm{NKB}(\mathrm{H})$, respectively, in 12 h. Data are mean $\pm \mathrm{SEM}$ from three independent experiments. ${ }^{*} p<0.05 ; * *<0.01 ; * * *<0.001$. 
the two functional motifs including the tumor vascular recognition sequence NGR or CNGRC, and the antiangiogenesis sequence of NK3R agonist to impart peptide flexibility and minimize potential steric interactions that would prevent binding [17]. Our results of in vitro and CAM assay indicated that the designed two peptides approximately retain the function of $\left[\mathrm{MePhe}^{7}\right] \mathrm{NKB}$ and showed even more visible anti-angiogenic effects in vitro experiments, which might embody the GG bridge linker maintain the structure of two functional domains. Our results in vivo showed that all peptides showed potent antitumor effects without severe toxic effect that which suggested by the finding that the body weight of peptides treated mice did not significantly altered. Meanwhile, NK3R-A1 exert more overt anti-tumor effect than that of NK3R-A2 and [MePhe $\left.{ }^{7}\right] \mathrm{NKB}$, suggesting that agonist analogues of NK3R conjugated with NGR motifs indeed have an advantage over $\left[\mathrm{MePhe}^{7}\right] \mathrm{NKB}$ on anti-tumor effects and the disulfide bridge of $\mathrm{c}(\mathrm{CNGRC})$ might not be well established, more pharmacokinetics experiments are ongoing.
In conclusion, these results indicated that the complex of NGR or CNGRC and the NK3R agonist are successful for eliciting anti-angiogenic effect. They might open a new gate leading to the anti-angiogenesis targeting therapy. Otherwise, our competition assays also demonstrated the anti-angiogenesis activities of peptides are depending on the activation of NK3R. Our work also proved that NGR-GG-DFF(MeF)GLM- $\mathrm{NH}_{2}$ could serve as a novel valued template for the development of antiangiogenesis drug against cancer.

\section{MATERIALS AND METHODS}

\section{Peptide synthesis}

NKB, [MePhe ${ }^{7}$ NKB, NK3R-A1, NK3R-A2 and the antagonist of NK3R, [Gly ${ }^{6}$ NKB[3-10], were synthesized using a manual peptide solid-phase synthesizer by Fluorenylmethoxycarbonyl (Fmoc) protocol as previously described and the information of the peptides were listed in Table 1. Lyophilized crude peptides were purified by
A
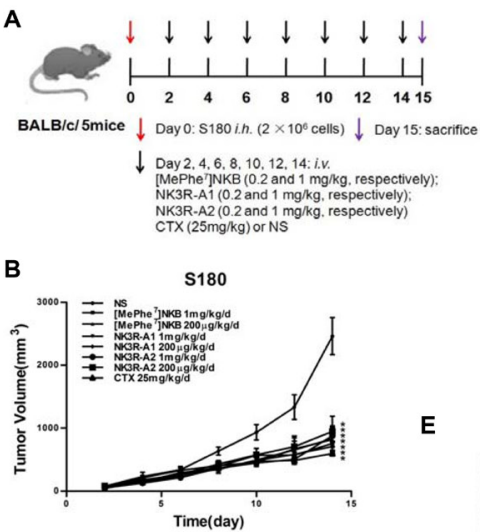

C

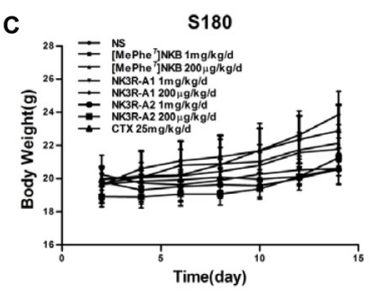

D
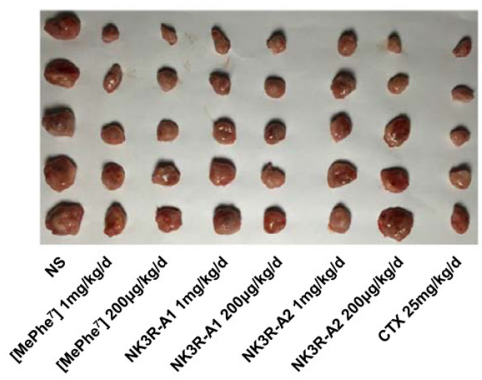

$\mathbf{F}$

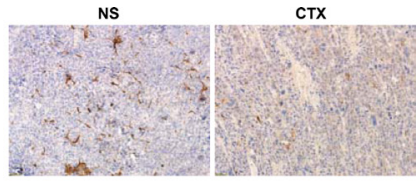

$1000 \mu \mathrm{g} / \mathrm{kg} / \mathrm{d}$
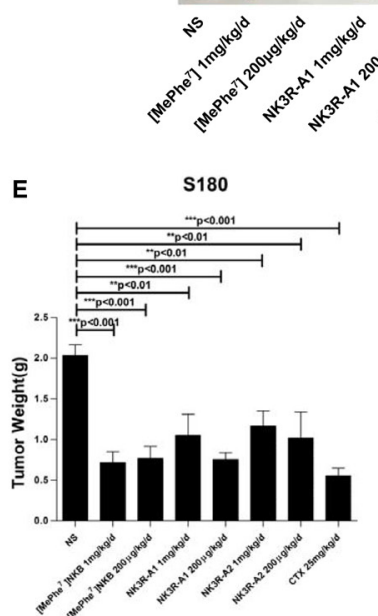

G
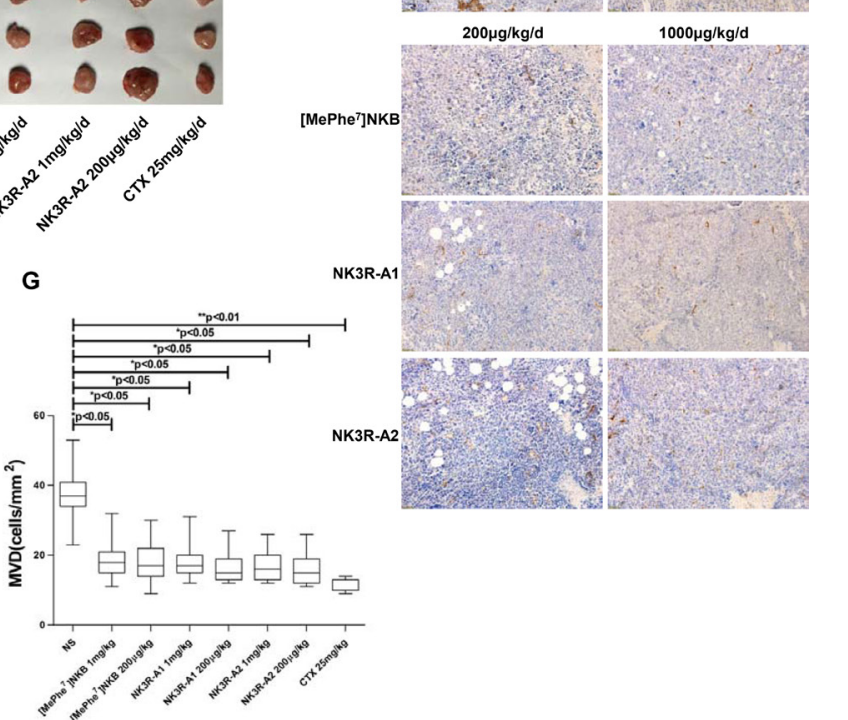

[MePhe $\left.{ }^{\top}\right]$ NKB

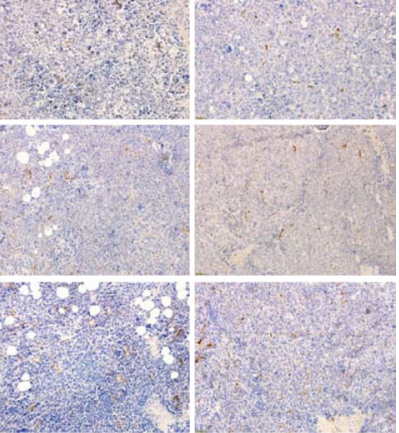

Figure 5: Effects of analogues, NK3R-A1, NK3R-A2 and [MePhe ${ }^{7}$ NKB, on tumor growth in S180 sarcoma-bearing BALB/c mice. (A) Mice treatment protocol: BALB/c micewere subcutaneously implanted with $2 \times 10^{6}$ cells/mouse on the right flank (day 0). Seventy-two hours after inoculation, forty mice with S180 cells were randomly divided into eight groups. Peptides were continuously administrated intravenously by tails for 14 days $(0.1 \mathrm{ml} / 10 \mathrm{~g}$, once a day): group 1 with NS (negative control), group 2 with

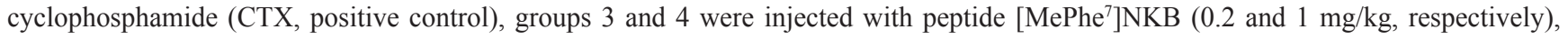
groups 5 and 6 were injected with peptide NK3R-A1 $(0.2$ and $1 \mathrm{mg} / \mathrm{kg}$, respectively), groups 7 and 8 were injected with peptide NK3R-A2 $(0.2$ and $1 \mathrm{mg} / \mathrm{kg}$, respectively). All mice were sacrificed after $24 \mathrm{~h}$ of the last administration, and the tumor tissues were excised and weighed. (B) The growth curves of the tumor were recorded with a caliper and the tumor volume was measured every two day according to the equation: tumor volume $=$ length $\times$ width $2 / 2$. (C) The body weight changes curve of each group of BABL/c mice during the intravenous administration of peptides for 14 days. (D-E) At the end of the experiment (day 15), the mice were sacrificed, and the tumors were isolated, photographed and weighed. (F-G) CD31 staining. Tumor tissues from each group were stained using immunohistochemistry for CD31 and representative photos were shown $(200 \times)(\mathrm{F})$, the evaluation of immunostaining for microvasculature density (MVD) in tumor tissues was displayed in bar graph $(\mathrm{G})$. Data are mean \pm SEM. * $p<0.05 ; * * p<0.01 ; * * *<0.001$. 
Table 1: Peptide agonists and antagonist for the tachykinin NK3 receptor

\begin{tabular}{|c|c|c|c|}
\hline Name & Sequence & Mr & References \\
\hline NKB & Asp-Met-His-Asp-Phe-Phe-Val-Gly-Leu-Met-NH ${ }_{2}$ & 1211.02 & [15] \\
\hline$[\mathrm{MePhe} 7] \mathrm{NKB}$ & Asp-Met-His-Asp-Phe-Phe-MePhe-Gly-Leu-Met- $\mathrm{NH}_{2}$ & 1272.48 & [17] \\
\hline$\left[\mathrm{Gly}_{6}\right] \mathrm{NKB}[3-10]$ & His-Asp-Phe-Gly-Val-Gly-Leu-Met-NH ${ }_{2}$ & 875.01 & [18] \\
\hline NK3R-A1 & Asn-Gly-Arg-Gly-Gly-Asp-Phe-Phe-MePhe-Gly-Leu-Met-NH ${ }_{2}$ & 1329.0 & Novel \\
\hline NK3R-A2 & Cys-Asn-Gly-Arg-Cys-Gly-Gly- Asp-Phe-Phe-MePhe-Gly-Leu-Met-NH ${ }_{2}$ & 1533.24 & Novel \\
\hline
\end{tabular}

Abbreviation: Relative Molecular Mass, Mr.

preparative reversed-phase HPLC on a C18 column with an elution gradient of $20-60 \%$ acetonitrile with $0.1 \%$ trifuoroacetic acid in water. Acquired peptides were confirmed by ESI-MS (KeTai, China).

\section{Animals and cell lines}

Female BALB/c mice, aged 5-8 weeks $(18 \pm 2 \mathrm{~g})$, were purchased from Henan Academy of Medical and Pharmaceutical Science (Certificate No. SCXK (Yu) 2011-0010, Henan, China). The animals had free access to food and water in cages that were maintained in a pathogenfree environment $\left(24 \pm 0.8^{\circ} \mathrm{C}\right.$, humidity of $\left.55 \pm 5 \%\right)$ with a 12 hours light/dark cycle. All animal experimental procedures were approved by Zhengzhou University committee for animal experiments. Human umbilical vein endothelial cells (HUVECs) and murine sarcoma S180 cell line were maintained in our laboratory. All cells were cultured in RPMI 1640 (Invitrogen, USA) with 10\% fetal bovine serum, $100 \mathrm{U} / \mathrm{ml}$ penicillin, and $100 \mu \mathrm{g} / \mathrm{ml}$ streptomycin at $37^{\circ} \mathrm{C}$ in a humidified atmosphere of $5 \% \mathrm{CO}_{2}$.

\section{Cell viability assay}

HUVECs were used to evaluate the effects of different concentrations of peptides $\left[\mathrm{MePhe}^{7}\right]$ NKB, NK3R-A1 and NK3R-A2. The effects of peptides $(5,25,100 \mu \mathrm{M})$ on cell proliferation were determined by a quantitative colorimetric assay with 3-[4,5-dimethylthiazol-2-yl]-2,5-diphenyl-tetrazolium bromide (MTT).

\section{Wound healing assay}

Wound healing assay was performed to validate the anti-angiogenic effect of peptides in vitro and investigate the relevant mechanism. $50 \mu \mathrm{M}$ of NK3 receptor antagonist, [Gly $\left.{ }^{6}\right] \mathrm{NKB}[3-10]$, was administrated 1 hour before adding agonists. Images of migrated cells were taken using an inverted microscope at $100 \times$ magnification after every $6 \mathrm{~h}$ of incubation in a humidified atmosphere with $5 \% \mathrm{CO}_{2}$ at $37^{\circ} \mathrm{C}$. The pictures were taken from three randomly selected fields and analyzed by Image J.

\section{Transwell migration assay}

The Transwell migration assay is a commonly used test to assess the migratory response of endothelial cells to angiogenic inducers or inhibitors. The effect of peptides [MePhe ${ }^{7}$ NKB, NK3R-A1 and NK3R-A2 $(1,5,25,100 \mu \mathrm{M})$ on HUVECs migration was performed using a Transwell system (BD, USA) with pore size of $8.0 \mu \mathrm{m}$ as described previously [34]. Five random views of successfully migrated cells were photographed and quantified under an inverted microscope. The competitive antagonism assay was conducted by using $\left[\mathrm{Gly}^{6}\right] \mathrm{NKB}[3-10]$.

\section{Chick chorioallantoic membrane (CAM) assay}

The CAM assay was carried out as described with slight modifications according to the procedure described by Le Noble FA et al previously [35]. $1 \mu \mathrm{M}$ of $\left[\mathrm{Gly}^{6}\right]$ NKB[3-10] were added to eggs 1 hour before adding the agonist to validate the anti-angiogenic role of peptides. Pictures were disposed with picture soft (NIS-Elements Basic Research, Nikon Corporation, Japan). The antiangiogenesis effect was calculated using the following equation : [( Vessel Number of CAM treated by drug/ (Vessel number of CAM treated by PBS)] $\times 100 \%=\%$ relative rate of vascular density. [(Vessel area of CAM treated by drug/(Vessel area of CAM treated by PBS)] $\times 100 \%=\%$ relative rate of vascular area. 


\section{The gelatin sponge-CAM assay}

The gelatin sponge-CAM assay was performed as previously described by Ritabbi D [36]. Briefly, sterilized gelatin sponges (Fukang Medical Devices Co. Ltd, Guilin, China) containing peptides were implanted onto CAM on day 8 of incubation. Embryos and membranes were fixed and cut in ovo after $48 \mathrm{~h}$ treated with peptides. Samples were sent to Servicebio Technology Company (Wuhan, China) to conduct special staining. The stained CAM tissues were observed by an inverted microscope $(400 \times)$.

\section{Mice Treatment}

The bearing mice model of S180 cells were performed following the protocol described previously [37]. Mice were injected (i.h.) with $2 \times 10^{6} \mathrm{~S} 180$ cells at day 0.24 hours later, [MePhe $\left.{ }^{7}\right] \mathrm{NKB}, \mathrm{NK} 3 \mathrm{R}-\mathrm{A} 1$ and NK3R-A2 $(0.2$ or $1 \mathrm{mg} / \mathrm{kg} / \mathrm{d}$ ) was administered by the intravenous (i.v.) route for 14 days. Mice were administered Normal Saline (NS) or CTX (25 mg/kg/d; Sigma-Aldrich, Rome, Italy) as negative control and positive control, respectively. Positive control group were i.v. administered $25 \mathrm{mg} / \mathrm{kg} / \mathrm{d}$ for two weeks. The tumor volumes were monitored every two days, and primary tumor volumes were calculated by the formula $\mathrm{V}=\mathrm{a} \times \mathrm{b}^{2} / 2$, where " $\mathrm{a}$ " is the longest dimension parallel to the skin surface and " $\mathrm{b}$ " is the dimension perpendicular to "a" and parallel to the surface. All mice were sacrificed after 24 hours of the last administration, and the tumor tissues were excised and weighed.

\section{Immunohistochemical staining}

The anti-CD31 antibody (bs-0195R) was purchased from Bioss Company (Beijing, China) and used according to the manufacturer's instructions. Tumor tissues were sent to pathology of Zhengzhou Yihe hospital to stain. The stained sample tissues were observed under an inverted microscope $(200 \times)$ using the method of Weidner [38].

\section{Statistical analysis}

Data were presented as mean \pm SEM. The statistical significances of difference between each group were analyzed by one-way analysis of variance (ANOVA). Statistical differences were presented at probability levels of $* p<0.05,{ }^{* *} p<0.01$, and ${ }^{* * *} p<0.001$.

\section{ACKNOWLEDGMENTS AND FUNDING}

This work was supported by the grant from the National Natural Science Foundation of China (Code: $81530005,81571547,81602537)$ and the Key Scientific Research Projects of the Higher Education Institutions of Henan province (17A180014).

\section{CONFLICTS OF INTEREST}

The authors have no conflicts of interest to declare.

\section{REFERENCES}

1. Folkman J. Tumor angiogenesis: therapeutic implications. New Eng J Med. 1971; 285:1182-1186.

2. Wang Z, Dabrosin C, Yin X, Fuster MM, Arreola A, Rathmell WK, Generali D, Nagaraju GP, El-Rayes B, Ribatti D, Chen YC, Honoki K, Fujii H, et al. Broad targeting of angiogenesis for cancer prevention and therapy. Semin Cancer Biol. 2015; 35:S224-243.

3. Cesca M, Bizzaro F, Zucchetti M, Giavazzi R. Tumor delivery of chemotherapy combined with inhibitors of angiogenesis and vascular targeting agents. Front Oncol. 2013; 3:259.

4. Simons M. Angiogenesis: where do we stand now? Circulation. 2005; 111:1556-1566.

5. Bergers G, Hanahan D. Modes of resistance to anti-angiogenic therapy. Nat Rev Cancer. 2008; 8:592-603.

6. Casanovas O. Cancer: Limitations of therapies exposed. Nature. 2012; 484:44-46.

7. Ribatti D. Tumor refractoriness to anti-VEGF therapy. Oncotarget. 2016; 7:46668-46677. doi: 10.18632/ oncotarget.8694.

8. Maggio JE. Tachykinins. Annual Review of Neuroscience. 1988; 11:13-28.

9. Maggi CA, Patacchini R, Rovero P, Giachetti A. Tachykinin receptors and Tachykinin receptor antagonists. Journal of Autonomic Pharmacology. 1993; 13:23-93.

10. Pal S, Wu J, Murray JK, Gellman SH, Wozniak MA, Keely PJ, Boyer ME, Gomez TM, Hasso SM, Fallon JF, Bresnick EH. An antiangiogenic neurokinin-B/thromboxane A2 regulatory axis. J Cell Biol. 2006; 174:1047-1058.

11. Almeida TA, Rojo J, Nieto PM, Pinto FM, Hernandez M, Martin JD, Candenas ML. Tachykinins and tachykinin receptors: structure and activity relationships. Curr Med Chem. 2004; 11:2045-2081.

12. Drapeau G, d'Orléans-Juste P, Dion S, Rhaleb NE, Regoli D. Specific agonists for neurokinin B receptors. Eur J Pharmacol. 1987; 136:401-403.

13. Hashimoto T, Uchida Y, Naminohira S, Sakai T. Tachykinin antagonist I: Specific, competitive and tissue-selective neurokinin B antagonists on contractile activity in smooth muscles. Jpn J Pharmacol. 1987; 45:570-573.

14. Gether U, Johansen TE, Schwartz TW. Chimeric NK1 (Substance P)/NK3 (Neurokinin B) Receptors: Identification of domains determining the binding specificity of Tachykinin agonists. J Cell Biol. 1993; 268:7893-7898.

15. Arap W, Pasqualini R, Ruoslahti E. Cancer treatment by targeted drug delivery to tumor vasculature in a mouse model. Science. 1998; 279:377-380. 
16. Curnis F, Sacchi A, Borgna L, Magni F, Gasparri A, Corti A. Enhancement of tumor necrosis factor alpha antitumor immunotherapeutic properties by targeted delivery to aminopeptidase N (CD13). Nature Biotechnol. 2000; 18:1185-1190.

17. Ellerby HM, Arap W, Ellerby LM, Kain R, Andrusiak R, Rio GD, Krajewski S, Lombardo CR, Rao R, Ruoslahti E, Bredesen DE, Pasqualini R. Anticancer activity of targeted pro-apoptotic peptides. Nature Med. 1999; 5:1032-1038.

18. Wickström M, Larsson R, Nygren P, Gullbo J. Aminopeptidase $\mathrm{N}$ (CD13) as a target for cancer chemotherapy. Cancer Sci. 2011; 102:501-508.

19. Pasqualini R, Koivunen E, Kain R, Lahdenranta J, Sakamoto M, Stryhn A, Ashmun RA, Shapiro LH, Arap W, Ruoslahti E. Aminopeptidase $\mathrm{N}$ is a receptor for tumorhoming peptides and a target for inhibiting angiogenesis. Cancer Res. 2000; 60:722-727.

20. Curnis F, Arrigoni G, Sacchi A, Fischetti L, Arap W, Pasqualini R, Corti A. Differential binding of drugs containing the NGR motif to CD13 isoforms in tumor vessels, epithelia, and myeloid cells. Cancer Res. 2002; 62:867-874.

21. Al-Husein B, Abdalla M, Trepte M, Deremer DL, Somanath PR. Antiangiogenic therapy for cancer: an update. Pharmacotherapy. 2012; 32:1095-1111.

22. Ferrara N. Vascular endothelial growth factor as a target for anticancer therapy. Oncologist. 2004; 2-10.

23. Awasthi N, Schwarz RE. Profile of nintedanib in the treatment of solid tumors: the evidence to date. Onco Targets Ther. 2015; 8:3691-3701.

24. Ferrara N, Hillan KJ, Gerber HP, Novotny W. Discovery and development of bevacizumab, an anti-VEGF antibody for treating cancer. Nat Rev Drug Discov. 2004; 3:391-400.

25. Ebos JM, Lee CR, Cruz-Munoz W, Bjarnason GA, Christensen JG, Kerbel RS. Accelerated metastasis after short-term treatment with a potent inhibitor of tumor angiogenesis. Cancer Cell. 2009; 15:232-239.

26. Regoli D, Boudon A, Fauchére JL. Receptors and antagonists for substance $\mathrm{P}$ and related peptides. Pharmacol Rev. 1994; 46:551-599.

27. Hoveyda HR, Fraser GL, Roy MO, Dutheuil G, Batt F, El Bousmaqui M, Korac J, Lenoir F, Lapin A, Noel S, Blanc S. Discovery and optimization of novel antagonists to the human neurokinin-3 receptor for the treatment of sex-hormone disorders (Part I). J Med Chem. 2015; 58:3060-3082.

28. Griebel G, Beeské S. Is there still a future for neurokinin 3 receptor antagonists as potential drugs for the treatment of psychiatric diseases? Pharmacol Ther. 2012; 133:116-123.

29. Drapeau G, D'Orléans-Juste P, Dion S, Rhaleb NE, Rouissi NE, Regoli D. Selective agonists for substance P and neurokinin receptors. Neuropeptides. 1987; 10:43-54.

30. Wang RE, Niu Y, Wu H, Hu Y, Cai J. Development of NGR-based anti-cancer agents for targeted therapeutics and imaging. Anticancer Agents Med Chem. 2012; 12:76-86.

31. Colombo G, Curnis F, De Mori GM, Gasparri A, Longoni C, Sacchi A, Lonqhi R, Corti A. Structure-activity relationships of linear and cyclic peptides containing the NGR tumorhoming motif. J Biol Chem. 2002; 277:47891-47897.

32. Zou M, Zhang L, Xie Y, Xu W. NGR-based strategies for targeting delivery of chemotherapeutics to tumor vasculature. Anticancer Agents Med Chem. 2012; 12:239-246.

33. Shim JS, Kim JH, Cho HY, Yum YN, Kim SH, Park HJ, Shim BS, Choi SH, Kwon HJ. Irreversible inhibition of CD13/Aminopeptidase $\mathrm{N}$ by the antiangiogenic agent curcumin. Chem Biol. 2003; 10:695-704.

34. Giordano A, D'Angelillo A, Romano S, D'Arrigo P, Corcione N, Bisogni R, Messina S, Polimeno M, Pepino P, Ferraro $\mathrm{P}$, Romano MF. Tirofiban induces VEGF production and stimulates migration and proliferation of endothelial cells. Vascul Pharmacol. 2014; 61:63-71.

35. Le Noble FA, Schreurs NH, van Straaten HW, Slaaf DW, Smits JF, Rogg H, Struijker-Boudier HA. Evidence for a novel angiotensin II receptor involved in angiogenesis in chick embryo chorioallantoic membrane. Am J Physiol. 1993; 264:R460-465.

36. Ribatti D, Nico B, Vacca A, Presta M. The gelatin spongechorioallantoic membrane assay. Nat Protoc. 2006; 1:85-91.

37. Wang H, Chen X, Chen Y, Sun L, Li G, Zhai M, Kang Q, Gao Y, Qi Y. Antitumor activity of novel chimeric peptides derived from cyclinD/CDK4 and the protein transductiondomain 4. Amino Acids. 2013; 44:499-510.

38. Weidner N. Current pathologic methods for measuring intratumoral microvessel density within breast carcinoma and other solid tumors. Breast Cancer Res Treat. 1995; 36:169-180. 